\title{
Management of the Nursing Processes of Internal Students in the Confrontation of the COVID-19
}

\author{
CrossMark

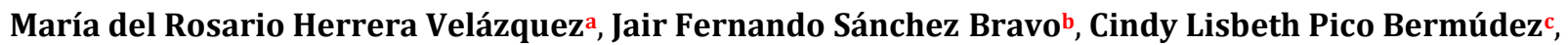 \\ Pedro Roger Villacreses Mendozad ${ }^{\mathrm{d}}$, Kaina Isabel Barberán Murillo
}

Manuscript submitted: 27 June 2020, Manuscript revised: 09 July 2020, Accepted for publication: 18 August 2020

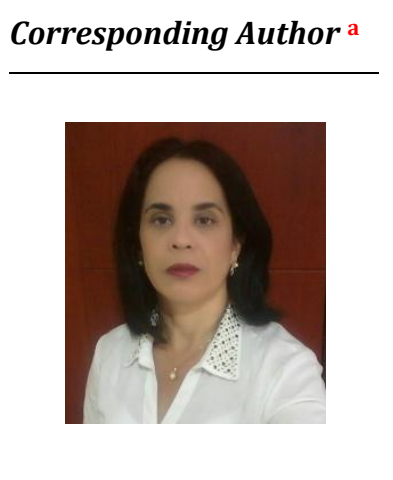

Keywords

nursing care;

pandemic;

practices;

pre-professional;

student experience;

\begin{abstract}
Nursing plays a key role in the management of services and care to guarantee the safety of patients and their professionals. This includes a diversity of care practices and initiatives arising from the new pandemic. The objective of the research was to describe the determining role of comprehensive student training for the correct management of nursing processes in the community boarding school, based on health education in the face of the current pandemic. A qualitative study was carried out, which describes the perception of four nursing interns in their rotation through the Health Center. Individual and group interviews were developed. It was evidenced that the students, during their training, have acquired abilities, skills, knowledge, attitudes, and values, in terms of biosafety measures, nursing management, and nursing care process, which allowed them to carry out the management of community nursing processes and the confrontation and combat of the pandemic caused by the SARS-CoV2 coronavirus, based on health education for the population. In the training of nursing professionals, the experiences acquired during the rotating internship constitute one of the main factors for the acquisition of knowledge and skills to provide holistically and quality care to patients and to achieve correct management of the processes in the daily chore. The decisive role of the integral formation of the student for the performance in the community boarding school and his later professional life is undoubted.
\end{abstract}

International Journal of Health Sciences (C) 2020. This is an open access article under the CC BY-NC-ND license (https://creativecommons.org/licenses/by-nc-nd/4.0/).

a Universidad Estatal del Sur de Manabí, Jipijapa, Manabí, Ecuador

b Universidad Estatal del Sur de Manabí, Jipijapa, Manabí, Ecuador

c Universidad Estatal del Sur de Manabí, Jipijapa, Manabí, Ecuador

${ }^{d}$ Universidad Estatal del Sur de Manabí, Jipijapa, Manabí, Ecuador

e Universidad Estatal del Sur de Manabí, Jipijapa, Manabí, Ecuador 


\section{Contents}

Abstract

1 Introduction.

Materials and Methods

Results and Discussions...

Conclusion

Acknowledgments

References

\section{Introduction}

COVID-19, MERS, and SARS are denominations of coronavirus, pathogens that cause respiratory infections, which can manifest as a common cold, or in more severe cases such as the so-called MERS, or Middle East respiratory syndrome; a severe acute respiratory syndrome that spread globally from China in 2002 (SARS) and was quickly controlled; or the new SARS-CoV2, in this case, known as COVID-19 (WHO, 2020; Tesini, 2020). The crisis generated by the COVID-19 pandemic at the international level has led to global health and social emergency that requires effective and immediate action from all healthcare centers.

Many scientists have carried out different investigations related to COVID-19, in the health sector it has been shown how violence and femicide have increased (Navarrete et al., 2020), studies related to the behavior of the education after the pandemic passes (Navarrete et al., 2020). Nursing plays a key role in the management of services and care, it tends to work with other areas of knowledge to guarantee the safety of the patient and their professionals. This includes a diversity of healthcare practices and initiatives derived from the new demand established by COVID-19.

As part of the training process, university students in general, and nursing students, in particular, develop pre-professional practices in the last year of studies, as a condition for the development of the degree project. With a duration of 720 hours, in it, the student will validate and receive feedback with comprehensive training, applying research, the method of the profession, and disciplinary knowledge in real work scenarios and problems, either in the institutional, business, or public community (Ibáñez et al., 2014; Biasutti, 2011). In the case of the Nursing Career of the State University of the South of Manabí-UNESUM, the pre-professional practices are part of the degree unit, developing them in two stages. In the first stage, students develop Community Internship I, where cognitive, procedural, and axiological learning results are strengthened, thus complying with the graduation profile of the nursing profession, with theoretical-practical reflective attitudes (Kalisch et al., 2010; Kalisch et al., 2012; Harrison, 2010). In a second stage, the students develop the Hospital Internship II, where the cognitive, procedural, and axiological learning results of the professionals in training are also strengthened, at this stage in the hospital area, where they develop and apply the competencies acquired at different levels training (Placencia et al., 2018).

That the pre-professional practices guarantee the achievement of the professional, generic, and investigative competencies, is a fundamental premise from the Nursing Career of UNESUM. This is achieved with a gear of the dynamic teaching-learning process of models and modes of action of the nursing profession, involving knowledge, attitudes, abilities, skills, capacities, and values that are transmitted and instilled in the student body through the training process. For this reason, the rotating internship is planned, monitored, and evaluated by an academic tutor of the nursing career, and in close collaboration and coordination with those responsible for the corresponding health institutions (Placencia et al., 2018; Miller et al., 2017; Swain et al., 2017).

In the current global context derived from the pandemic generated by the SARS-CoV2 coronavirus, the eighth-semester nursing students of UNESUM, joined the boarding school since May 2020, already when the situation in the world and the country was of generalized alarm and numerous cases of patients arriving at the different community and hospital care centers. In this sense, and as part of the training process, this research was developed to describe the determining role of comprehensive student training for the correct management of nursing processes in community boarding schools, based on health education for the

Velázquez, M. del R. H., Bravo, J. F. S., Bermúdez, C. L. P., Mendoza, P. R. V., \& Murillo, K. I. B. (2020).

Management of the nursing processes of internal students in the confrontation of the COVID-19. International Journal of Health Sciences, 4(2), 24-30. https://doi.org/10.29332/ijhs.v4n2.441 
confrontation and combat of COVID-19 (Dashraath et al., 2020; Pandey et al., 2010; Darlenski \& Tsankov, 2020).

\section{Materials and Methods}

A descriptive qualitative study was carried out in the city of Jipijapa. We worked with 4 nursing interns who were in the eighth semester and developed their pre-professional practices in the community stage (Internship I), being in direct contact with the population in primary care centers. Individual and group interviews were conducted with them and research aimed at analyzing their student preparation in terms of the abilities, skills, knowledge, attitudes, and values acquired in the different levels of university education in terms of biosecurity measures, management of nursing, and nursing care process, which allowed her to carry out the management of community nursing processes to confront and combat the pandemic caused by the SARS-CoV2 coronavirus, based on health education to the population.

\section{Results and Discussions}

The Rotary Internship takes place in the last mandatory year (eighth and ninth semesters) before obtaining the professional title of Bachelor (s) in Nursing, depends on the Coordination of the Career, under the responsibility of the Coordinating Teacher of the program and the Heads of Hospital and Community Units, who guide, coordinate and plan the normal development of activities together with the Head of the corresponding Service where the rotation of the pre-professional practice is carried out. Thus, the students develop tasks of managing nursing processes sequentially in the Services of:

a) Primary health care, which includes community fieldwork and care in Health Centers. (Community Internship)

b) Management in health services in the areas of Internal Medicine, Surgery, Maternal and Child, Pediatrics, Emergencies, Intensive Care, Neonatology. (Hospital Internship).

In this case, the perception, experience, and criteria of the internal students who developed their preprofessional practices in the community are described, and how they perceive their training to face two new aspects in their lives, such as joining the system national health as one more nursing staff and on top of this, do it in an extreme pandemic situation. In this case, the perception, experience, and criteria of the internal students who developed their pre-professional practices in the community are described, and how they perceive their training to face two new aspects in their lives, such as joining the system national health as one more nursing staff and on top of this, do it in an extreme pandemic situation.

The unanimous feeling of the inmates is that the teaching-learning process in university classrooms has allowed them to face this new experience, and they also report that in health care environments they have acquired new knowledge. They describe that being organized, efficient, and providing quality services has allowed them a correct job performance, making possible the fulfillment of nursing roles in the health subcenters where they worked. During the process of pre-professional practices, they have been guided by teachers from UNESUM who have facilitated the teaching-learning process (online), as well as by graduates from different health centers (face-to-face). They note that the learning environment generated in the reality of a health institution is different from the one that exists in the classroom.

Likewise, they ensure that before entering the rotating internship, they have many questions about the perception of learning environments, some of them are due to the role they will play in the future once they graduate, on other occasions they feel frustration as they perceive negative attitudes and unsatisfactory. They argue that university training allowed them to develop abilities and skills that facilitated their active participation in the processes developed in health centers, finding solutions, exploring, proposing new ideas. They feel that it is not only an intellectual process but that it is linked to individual performance and the emotional aspect, emphasizing that according to their way of acting, they hope to develop a good professional job. 
Within the rotating internship they have acquired and applied knowledge, in addition to developing skills for patient care, they have modified attitudes, which has helped them to make autonomous decisions and act in the best possible way in times of pandemic. These knowledge, skills, abilities and values acquired during university training and reinforced during pre-professional practices in the community cycle, have allowed them to develop the management of nursing processes, for which they argue that positive thinking and the commitment to the user's care, knowing that there are problems, conflicts, and the need to learn how to solve these situations. Doctors, graduates, and interns participate in this management through health education to the population, thus developing teamwork.

To fulfill the functions assigned as health personnel, trust, cooperation, effort, organization, and active listening have been fostered in the inmates. They feel that they are prepared to face conflicts, listen to opinions different from their own, and accept criticism, respecting the ethical values of the profession, which are reflected in the inmates' modes of action (Pasarín et al., 2013).

By analyzing the nursing management performed by the inmates in the prevention of COVID-19, the fundamental and important role is demonstrated, not only in the recovery and rehabilitation of infected patients but also in the prevention of contagions. The staff who are in the front row in the battle against the coronavirus are the nurses, who are with the COVID-19 patients 24 hours a day until they recover. Nursing work goes beyond the hospital environment, in the primary care area they have used elements of communication, dialogue, agency, and advocacy that favor the development of a liaison role between preventive indications, the responses that people have to their conditions, and the possibilities that the health system has to provide care.

The most relevant interventions developed by the boarding students were aimed at strengthening hygiene habits such as frequent hand washing, continuous use of masks, and social distancing, thus contributing to the health education of the population and consequently to the decrease of the mortality and contagion rate. In the same way, they perceive that their actions have significantly helped the health units not to collapse in their entirety, giving the possibility of offering quality and warm care to patients who come to the health area.

Another aspect investigated was the preparation of the inmates in terms of biosafety measures to come into contact with infected patients. In this sense, they refer that what was learned during the student stage is fulfilled, since biosafety measures such as the placement of personal protective equipment, hand washing, and education to the population are combined with the teamwork carried out to better cope COVID-19.

The management of nursing processes undertaken by the students in their community boarding school and that allowed the community to respond to the current pandemic are shown in figure 1.

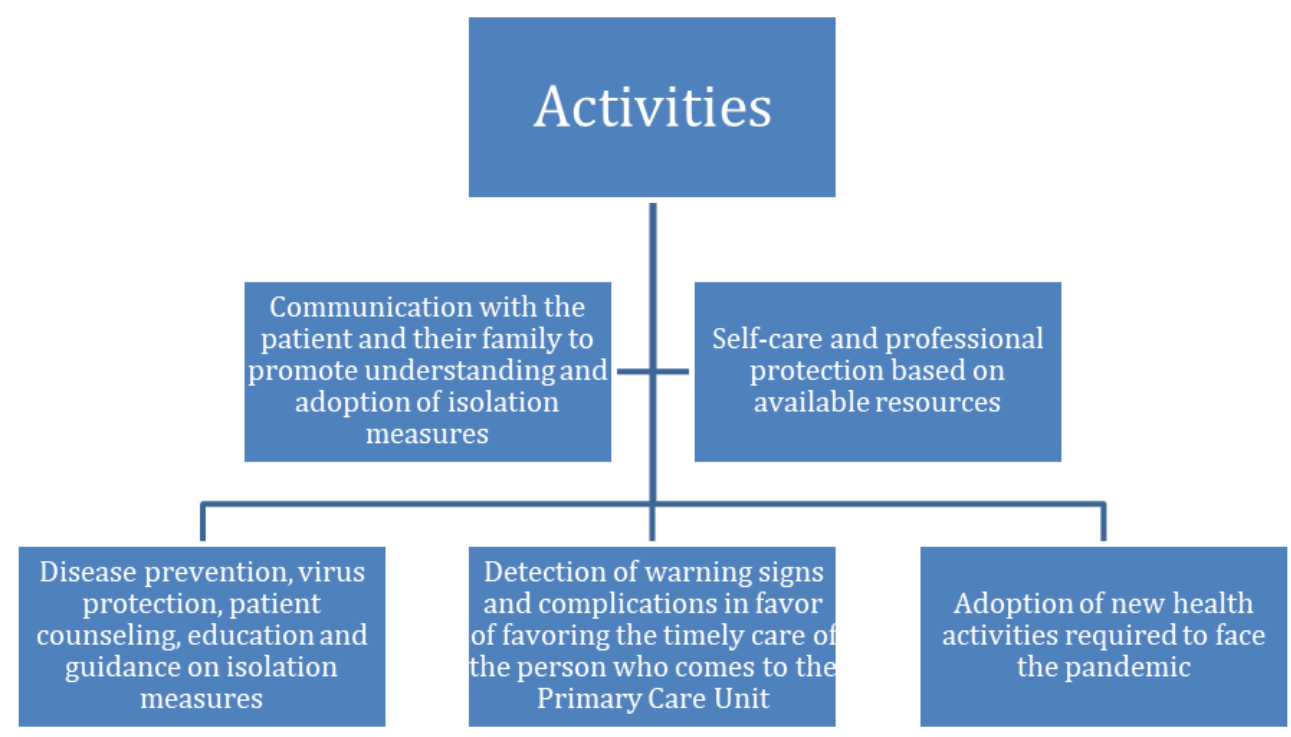

Figure 1. Nursing processes in the face of the pandemic

Velázquez, M. del R. H., Bravo, J. F. S., Bermúdez, C. L. P., Mendoza, P. R. V., \& Murillo, K. I. B. (2020).

Management of the nursing processes of internal students in the confrontation of the COVID-19. International Journal of Health Sciences, 4(2), 24-30. https://doi.org/10.29332/ijhs.v4n2.441 
It is considered to be a necessity in the services of health the preparation of professionals to work in a team and develop their skills on technical or functional knowledge, problem-solving skills, and decision-making and interpersonal skills such as risk acceptance, useful criticism, objectivity, knowing how to listen, offer the benefit of the doubt and recognize the interests and achievements of others (Beltrán González et al., 2018).

The recent appearance of COVID-19 requires the understanding of the experience of the disease, its transmission, severity, isolation, and the analysis of the management of the care carried out. This experience affects both the patient himself and the general population, healthcare personnel, the family environment, or other confinement environments. Therefore, it is necessary to carry out studies to evaluate and understand this experience, in addition to learning for future situations with similar epidemiological and clinical characteristics, even though they may occur in different contexts.

Undoubtedly, pre-professional practices are an essential part of professional training and in preparing the student to face working life after graduation. It prepares you to face and resolve conflicts, to work in a team, to solve real problems inherent to your profession, and in the specific case of nursing, to manage the nursing processes correctly and efficiently, which allows user satisfaction. For this, during their training process, the student will acquire abilities, skills, knowledge, and values, which will be forged in this last stage of training. Besides, at this stage, the student exchanges with health actors, which gives them a vision of their future actions as a professional with values, knowledge, and skills that allow them to perform well in the future (Cedeño \& Santos, 2017; Herrera Velázquez et al., 2018).

\section{Conclusion}

In the training of nursing professionals, the experiences acquired during the rotating internship constitute one of the main factors for acquiring the knowledge and skills to provide holistically and quality care to patients and achieve correct management of nursing processes in daily life. There is no doubt the decisive role of the integral formation of the student for the correct management of the nursing processes in the community boarding school, based on health education for the confrontation and combat of COVID-19.

\section{Acknowledgments}

To all the doctors, nurses, and students who have devotedly worked to cure those contaminated by Covid-19. 


\section{References}

Beltrán González, B., Vega Díaz, T., Sarduy Pérez, G., \& Santandreu Uriarte, E. (2018). Gestión por procesos en los servicios de salud y el trabajo en equipo: consideraciones metodológicas. EDUMECENTRO, 10(1), 236242.

Biasutti, M. (2011). The student experience of a collaborative e-learning university module. Computers \& Education, 57(3), 1865-1875. https://doi.org/10.1016/j.compedu.2011.04.006

Cedeño, L., \& Santos, J. (2017). La práctica pre-profesional: vía para la formación profesional integral desde sus incidencias en la investigación. Universidad y Sociedad, 9(3), 109-14.

Darlenski, R., \& Tsankov, N. (2020). Covid-19 pandemic and the skin-What should dermatologists know?. Clinics in Dermatology. https://doi.org/10.1016/j.clindermatol.2020.03.012

Dashraath, P., Jeslyn, W. J. L., Karen, L. M. X., Min, L. L., Sarah, L., Biswas, A., ... \& Lin, S. L. (2020). Coronavirus disease 2019 (COVID-19) pandemic and pregnancy. American journal of obstetrics and gynecology. https://doi.org/10.1016/j.ajog.2020.03.021

Harrison, T. M. (2010). Family-centered pediatric nursing care: state of the science. Journal of pediatric nursing, 25(5), 335-343. https://doi.org/10.1016/j.pedn.2009.01.006

Herrera Velázquez, M., Calderón Macías, M., Zambrano Santos, R., \& Placencia López, B. (2018). Acreditación y evaluación de los procesos en la carrera de Enfermería en la Universidad Estatal del Sur de Manabí. Educación Médica Superior, 32(4), 108-120.

Ibáñez, M. B., Di Serio, Á., Villarán, D., \& Kloos, C. D. (2014). Experimenting with electromagnetism using augmented reality: Impact on flow student experience and educational effectiveness. Computers \& Education, 71, 1-13. https://doi.org/10.1016/j.compedu.2013.09.004

Kalisch, B. J., \& Lee, K. H. (2010). The impact of teamwork on missed nursing care. Nursing outlook, 58(5), 233241. https://doi.org/10.1016/j.outlook.2010.06.004

Kalisch, B. J., \& Lee, K. H. (2012). Missed nursing care: Magnet versus non-Magnet hospitals. Nursing outlook, 60(5), e32-e39. https://doi.org/10.1016/j.outlook.2012.04.006

Miller, D. M., Khalil, K., Iskaros, O., \& Van Amburgh, J. A. (2017). Professional and pre-professional pharmacy students' perceptions of team based learning (TBL) at a private research-intensive university. Currents in Pharmacy Teaching and Learning, 9(4), 666-670. https://doi.org/10.1016/j.cptl.2017.03.001

Navarrete, D., Patiño, G., Villamil, A., Quijije, N., Mantilla, Y., \& Rodríguez, M. (2020). Education before the Covid-19 Pandemic. Journal of Advanced Research in Dynamical and Control Systems, 12(7), 604-610.

Navarrete, D., rodríguez, M., \& Jimenez, O. (2020). Gender Violence on Pandemic of COVID-19. International Journal of Health Sciences, 4(2), 10-18. https://doi.org/10.29332/ijhs.v4n2.437

Pandey, A., Patni, N., Singh, M., Sood, A., \& Singh, G. (2010). YouTube as a source of information on the H1N1 influenza pandemic.American journal of preventive medicine,38(3), e1-e3. https://doi.org/10.1016/j.amepre.2009.11.007

Pasarín, M., Berra, S., González, A., Segura Benedicto, A., Tebé, C., \& García Altés, A. (2013). Evaluación de la atención primaria de salud. Gaceta Sanit, 27(1).

Placencia, M., Calderón, M., Baque, C., Pincay, M., Solórzano, S., \& Villacreses, G. (2018). Rediseño curricular de la Carrera de Enfermería. (C. D. innovación, Ed.) Alcoy (Alicante): Editorial Área de Innovación y Desarrollo.

Swain, C. T., Bradshaw, E. J., Whyte, D. G., \& Ekegren, C. L. (2017). Life history and point prevalence of low back pain in pre-professional and professional dancers. Physical Therapy in Sport, 25, 34-38. https://doi.org/10.1016/j.ptsp.2017.01.005

Tesini, B. (2020). Manual MS. Coronavirus y síndromes respiratorios agudos (COVID-19, MERS y SARS). Recuperado el 3 de agosto de 2020, de https://www.msdmanuals.com/es/hogar/infecciones/virusrespiratorios/coronavirus-y-s\%C3\%ADndromes-respiratorios-agudos-covid-19-mers-y-sars

Velázquez, M. del R. H., Bravo, J. F. S., Bermúdez, C. L. P., Mendoza, P. R. V., \& Murillo, K. I. B. (2020).

Management of the nursing processes of internal students in the confrontation of the COVID-19. International Journal of Health Sciences, 4(2), 24-30. https://doi.org/10.29332/ijhs.v4n2.441 


\section{Biography of Authors}

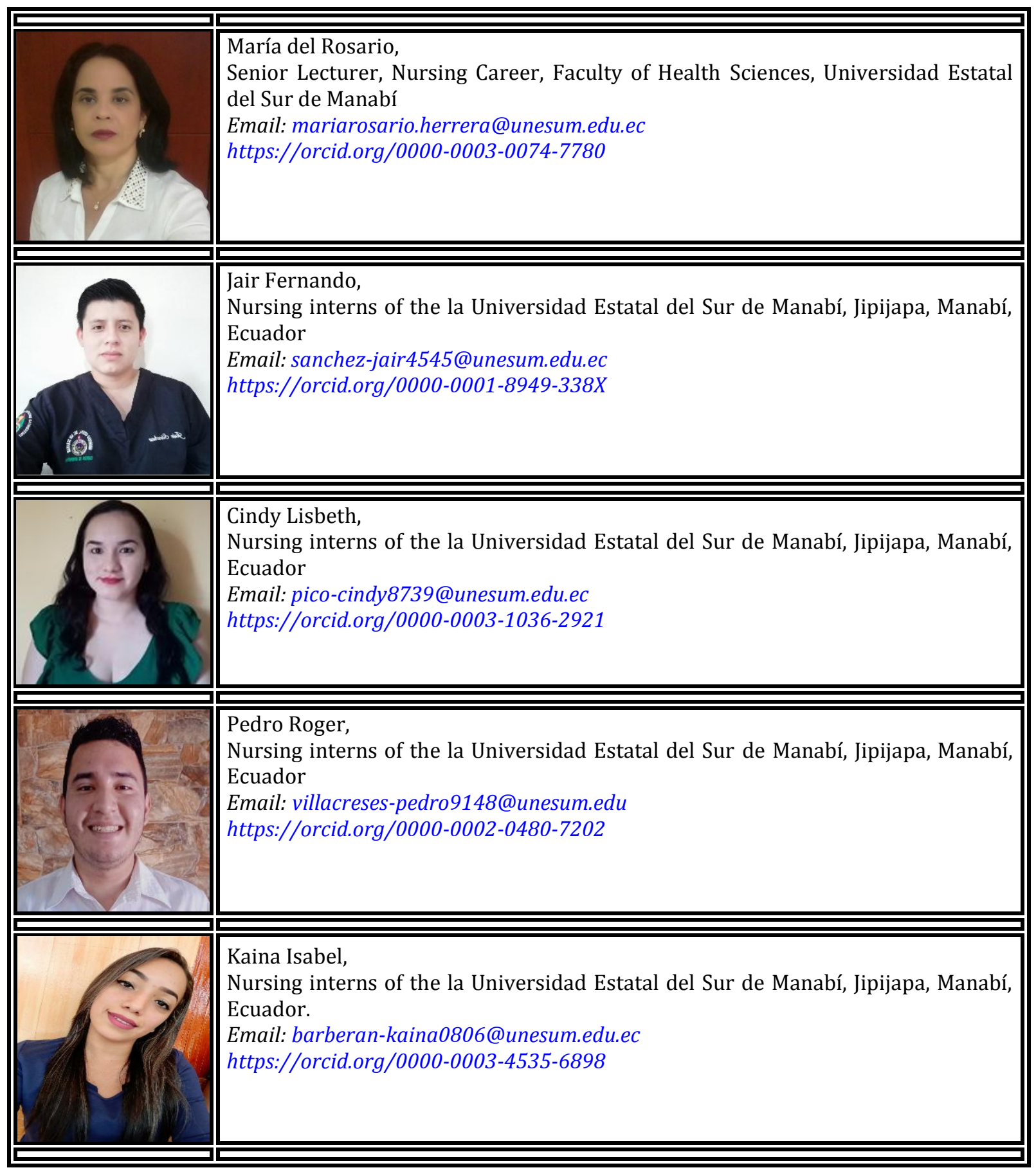

